UDC $662.749 .2: 543.813: 669.162 .263 .22: 669.162 .283: 669.788: 669.784 \quad$ 論 コークス揮発分中に含まれる水素と炭素についで

張東 植**. 館充**

\title{
On the Hydrogen and Carbon Contained in the Volatile Matter of Metallurgical coke
}

Tongshik Chang and Mitsuru TAte

Synopsis :

A fundamental study on the dependency of hydrogen and carbon contents in the volatile matter of coke on temperature and particle size has been carried out.

The results obtained are as follows:

1) Small size coke (or coke breeze) contains more hydrogen in volatile matter than large size coke.

2) The degree of volatilization of hydrogen depends on both of teniperature and particle size, but the effect of the former is more remarkable.

3) Main elemental components in the volatile matter are hydrogen and carbon, and the $\mathrm{C} / \mathrm{H}$ ratio varies from $2 \cdot 0$ in case of small size coke to $2 \cdot 6$ in case of large size coke.

4) Experimental formula expressing the dependency of the hydrogen volatilization on temperature and particle size are obtained.

\section{1. 緒言}

コークス揮発分中の水素含有量ならびにその気化速度 に関する情報は高炉における水素ガスの利用率を評価す る上で重要な意義を持つものであるが，この種の情報は 極めて少なく，またコークス中の水素として報告されて いる值もまちまちで, どの值を採用するかによつて水素 利用率の值が変わつてくる.

これまでコークス揮発分の組成に関する情報は若干報 告12)されているが, 揮発分中の水素気化量ならびに炭素 気化量の温度と粒度依存性に関する報文はほとんどみら れない.

本調査ではコークスの揮発分中に含まれる水素の絶対 量, 水素源の化学的成分, さらに揮発分中の水素気化量 と炭素気化量の温度ならびに粒度依存性に関する基礎的 調查を行なつたので，その結果を報告する。

\section{2. 実験装置および実䀦条件}

\section{$2 \cdot 1$ 実験装置と方法}

装置を Fig. 1 に示す. 基本的には Liebig 法3)を採
用し，これを実験目的にそうよう若干改良したものであ る.

この装置はキフリアーガス清浄部, 電気炉部, 吸収装 置部の 3 つの部分からなり, 電気炉としては試料加熱用 のものと燃焼用のものがある.これにより任意温度に加 熱した試料に $\mathrm{N}_{2}$ キャリアーガスを流して，揮発分のみ 燃焼管へ送り込み，揮発分中に含まれる水素と炭素を $\mathrm{H}_{2} \mathrm{O}$ と $\mathrm{CO}_{2}$ に酸化した後, これを吸収装置に送るよ うになつている. 複数個の $\mathrm{H}_{2} \mathrm{O}, \mathrm{CO}_{2}$ 吸収管はパラレ ルに連結されており，これらを一定時間おきに切りかえ て使用し, その重量変化から, それぞれの時点における 水素量と炭素量を算出した.

コークス中水素の絶対量を測定する時は,キォリアー ガスとして $\mathrm{O}_{2}$ ガスを流して測定を行なつた.

Fig. 1 の下部の図は試料管の棈造と燃焼管の充填㓣を 示す. 試料は充填層とし，この廨内の温度が測定できる ようになつている. 燃焼管内は酸化第 2 銅と銀銅が充填 されており，酸化第 2 銅は揮発分中の水素之炭素成分を $\mathrm{H}_{2} \mathrm{O}$ と $\mathrm{CO}_{2}$ に酸化し, 銀銅は揮発分中の $\mathrm{S}$, ハロゲン 物などを除去する作用をもつており，酸化第 2 銅部は

* 昭和 48 年 10 月本会講演大会にて発表 昭和 49 年 5 月 8 日受付 (Received May 8, 1974)

** 東京大学生産技術研究所 (Institute of Industrial Science, the University of Tokyo, Roppongi, Minatoku, Tokyo 106)

*** 東京大学生産技術研究所工博 (Institute of Industrial Science, the University of Tokyo) 
(Gas cleaning apparatus)

(Electric furnoce)

(Gas absorbing apparatus)

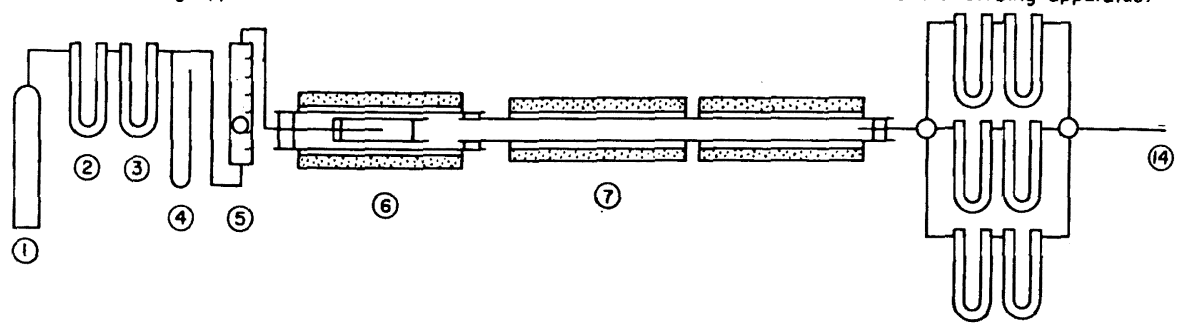

(3) (2)

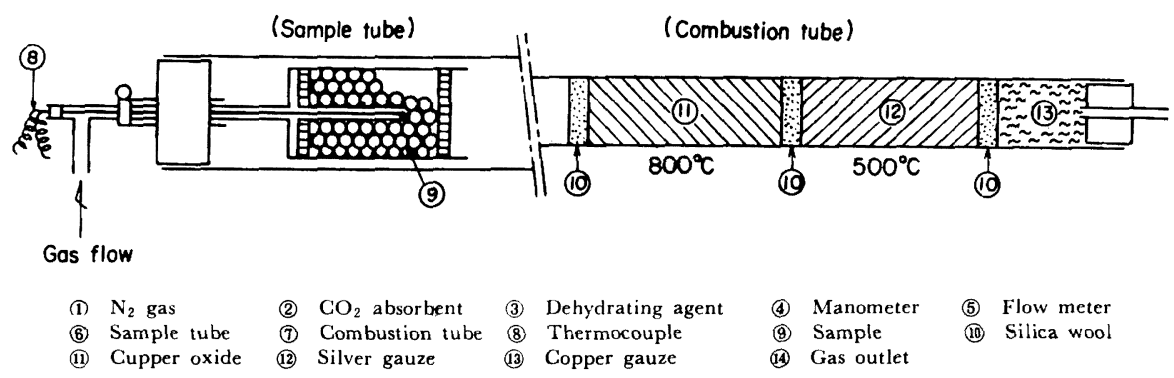

Fig. 1. Schematic diagram of experimental apparatus.

Table 1. Experimental conditions.

\begin{tabular}{|c|c|c|c|}
\hline Condition & (A) & (B) & (C) \\
\hline Coke size & $\begin{array}{c}4.3 \sim 10.0 \mathrm{~mm} \\
20.0 \sim 25.0 \mathrm{~mm} \\
46^{*} \mathrm{~mm}\end{array}$ & $\begin{array}{c}4.3 \sim 10.0 \mathrm{~mm} \\
20.0 \sim 25.0 \mathrm{~mm} \\
46 * \mathrm{~mm}\end{array}$ & $\begin{array}{c}6.73 \sim 9.52 \mathrm{~mm} \\
9.52 \sim 12.70 \mathrm{~mm} \\
12 \cdot 70 \sim 15.0 \mathrm{~mm}\end{array}$ \\
\hline Sample weight & $2 \mathrm{~g}$ & $6 \mathrm{~g}$ & $50 \mathrm{~g}$ (coke bed) \\
\hline Temperature & $800^{\circ} \mathrm{C}$ & Room temp. $\sim 600^{\circ} \mathrm{C}$ & $700,900,1100^{\circ} \mathrm{C}$ \\
\hline Carrier gas & $\mathrm{O}_{2}$ & Super dry $\mathrm{N}_{2}$ & Super dry $\mathrm{N}_{2}$ \\
\hline Gas flow rate & $50 \sim 100 \mathrm{ml} / \mathrm{min}$ & $1 \mathrm{l} / \mathrm{min}$ & $1 l / \min$ \\
\hline
\end{tabular}

* Harmonic mean diameter of large size coke.

$800^{\circ} \mathrm{C}$ ，銀銅部は $500^{\circ} \mathrm{C}$ に保持して実験を行なつた。

\section{2 実験条件}

調查は次の 3 項目について行なつた。

（A）コークス揮発分中の水素絶対量の粒度依存性に ついて.

（B）コークス中の付着水と細孔内吸着水の温度およ び粒度依存性について。

(C) コークス揮発分中の水素量と炭素量の温度およ び粒度依存性について。

(A) (B)の試料は, Table 1 の(A), (B) 項に示すご とく, 第 23 次操業に用いたコークスを $4.3 \sim 10.0 \mathrm{~mm}$, 20.0 25.0 mm の粒度に 篩い分けしたもの 2 種, 生産
高炉用 1 種（調和平均粒度， $46 \mathrm{~mm}$ ) と粒度範囲の異な るもの 3 種を選び，これを 80 mesh に粉砕し，(A)に ついては $100^{\circ} \mathrm{C}$ にて十分乾燥した後，(B)については 常温から試料として用いた（C)の試料は，第 22 次操 業に用いたコークスを Table 1 の $(\mathrm{C})$ 項に 示した 3 種 の粒度範囲に篩い分けしたものを選び，これらを予め別 灯で $500^{\circ} \mathrm{C} て ゙ ~ 30 \mathrm{~min}$ 加熱し，コークス中の付着水と 細孔内吸着水を除去した試料を用いた. その他の実験条 件を Table 1 に示した. Table 1 の温度は試料(Fig. 1 の 9 部) の加熱蕰度を示し, キャリアーガス $\mathrm{N}_{2}$ は露点 $-65^{\circ} \mathrm{C}$ 以下の超乾燥 $\mathrm{N}_{2}$ (水分含有量, $10 \mathrm{PPM}$ 程度) を用いた。 また本実験で用いたコークスの化学的成分を 
Table 2. Chemical analysis of tested coke.

\begin{tabular}{l|c|c}
\hline & 22 nd operation & 23 rd operation \\
\hline Fixed carbon & $87 \cdot 90 \%$ & $86 \cdot 68 \%$ \\
\hline Volatile matter & $2 \cdot 00 \%$ & $2 \cdot 17 \%$ \\
\hline Total sulpher & $0 \cdot 43 \%$ & - \\
\hline Ash & $10 \cdot 10 \%$ & $11 \cdot 15 \%$ \\
\hline
\end{tabular}

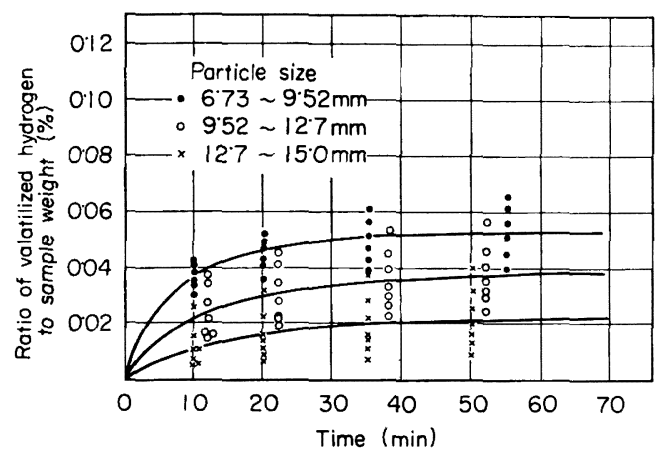

Fig. 2. Volatilized hydrogen content from coke of $50 \mathrm{~g}$ at $900^{\circ} \mathrm{C}$

Table 2 に示した,

本実験に先だち, Table 1 の(C)の温度 $900^{\circ} \mathrm{C}$ 一定 で，各粒度についての再現性試験を試みた。この結果を Fig. 2 に示した. この図から明らかなように同一条件下 での水素気化量の再現性は悪く, どの粒度についても測 定值にバラツキがみられた：しかしそのバラッキを考虑 しても平均的な水素気化量 (Fig. 2 中の実線部) は粒度 依存性があることがわかる，したがつて本実験でのデー タの定量化にあたつては, 同一条件にて少なくとも数点 の実験を試み, 得られたデータを平均化して代表値とし た.

\section{3. 実験結果および考察}

\section{1 コークス挥無分中の 水素絶対量の 粒度依存性につ いて}

ここでいう水素絶対量とは $100^{\circ} \mathrm{C}$ で乾燥したコーク ス中に含まれる細孔内吸着水の水素, 遊離水素, 炭化水 素らの水素の総和の試料量に対する割合を意味する.

本調査は Table 1 の(A)にもとうきき, 80 mesh に粉 砕した試料に $\mathrm{O}_{2}$ ガスを流してコークスを完全に $\mathrm{H}_{2} \mathrm{O}$ と $\mathrm{CO}_{2}$ に酸化し, 得られた $\mathrm{H}_{2} \mathrm{O}$ 量からコークス中の 全水素量を換算し，それの試料量に対する割合（水素絶 対量を意味する）の粒度依存性を調べた。この結果を Fig. 3 に示した. これからわかるように水素絶対量は粒

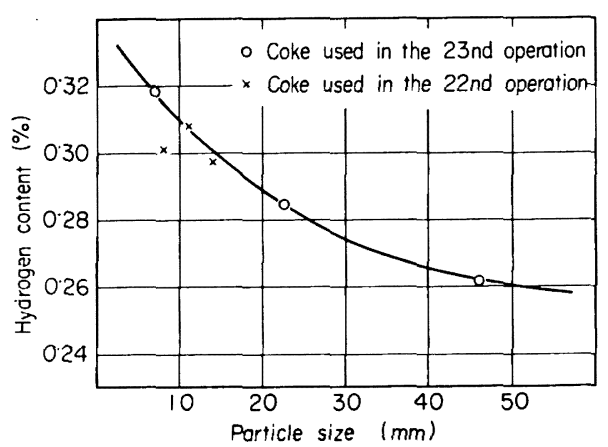

Fig. 3. Relation between particle size and hydrogen content.

度に依存し，試験炉用コークスの粒度範囲では $0.3 \%$ 前 後の水素含有量を示すのにたいし, 生産高炝用コークス 粒度では $0.26 \%$ と粒度が大きくなるにしたがつて減少 することがわかる。

このような粒度依存性は, 他のコークス成分について も当然考えられるが，水素絶対量についていえば原料炭 の品種, 組成, ないしは乾留条件によつて異なつてくる とみるのが自然のようである.

\section{2 コークス中の付着水と 細孔内吸着水の温度および} 粒度依存性について

コークス中の水素絶対量の水素源成分の一つと考えら れる細孔内吸着水 $\left(100^{\circ} \mathrm{C}\right.$ 以上で気化する水分を意味す る）の温度および粒度依存性，ならびに細孔内吸着水由 来の水素量について調べた結果を Fig. 4, Fig. 5 に示 した.なおこの場合，装置は Fig. 1 の燃焼管部を撤去 し，吸収装置を直接試料管に接続して用いた。試料は 3.1 項で用いたものと同じで，実験条件は Table 1 の (B)にもとづいて行なつた。温度は常温からある温度ま

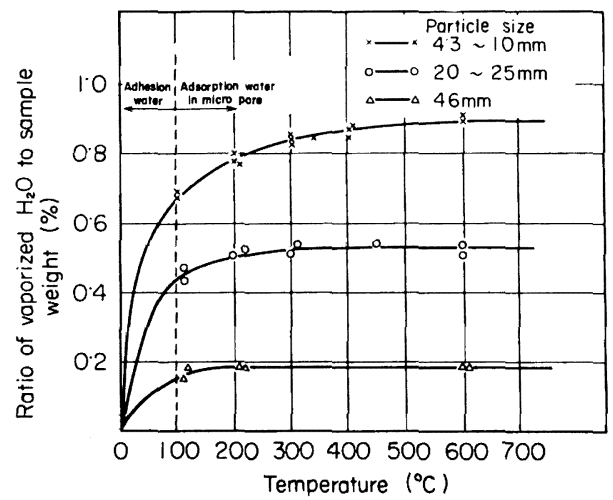

Fig. 4. Relation between vaporized $\mathrm{H}_{2} \mathrm{O}$ and temperature on several particle sizes. 


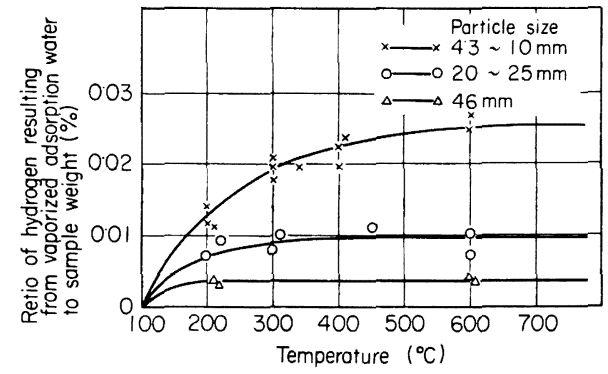

Fig. 5. Relation between hydrogen resulting from vaporized adsorption water and temperature on several particle sizes.

で加熱し，その温度で平衡に達したら，次の温度まで昇 温し, その温度で平衡達したら, さらに次の温度まで 昇温するという方法で段階的に昇温していつた.

Fig. 4 はコークス中の水分の気化量（水分気化量の試 料量に対する割合）を各粒度について調べたもので， $100^{\circ} \mathrm{C}$ 以下で気化する水分を付着水, $100^{\circ} \mathrm{C}$ 以上で気化 する水分を細孔内吸着水とすると，この細孔内吸着水の 気化量も粒度依存性を示し, 粒度が小さいものほど多量 発生し, しかも $600^{\circ} \mathrm{C}$ 近くまで細孔内吸着水が発生す ること, 粒度の大きい生産高炉用コークスの場合は細孔 内吸着水は少なく, $200^{\circ} \mathrm{C}$ 近くで気化してしまうことが わかる.

Fig. 5 は細孔内吸着水から生じる水素量の試料量に対 する割合を示した．この Fig. 5 と Fig. 3 から各粒度 における細孔内吸着水由来の気化水素量の総水素量に対 する割合を求めると，10 $\mathrm{mm}$ 以下の粒度範囲では約 $8 \%$ に相当しており，生産高炉用コークスでは $1.5 \%$ と小さ な値を示していることがわかる.

したがつて生産高炉用コークスではコークス中に含ま れる水素量はほとんど遊離水素と炭化水素系の水素であ り，粒度が $10 \mathrm{~mm}$ 以下になると $8 \%$ と若干ではあるが 細孔内吸着水中の水素が関与してくるものと思われる.

コークス中の水分については, 城ら゙战でれに関連し た調査を行なつて㧍り，彼らはコークス中の水分含有量

$\left(120^{\circ} \mathrm{C}\right.$ 以上）を赤熱コークスの消火法（湿式と乾式） の相違によつて比較しており, 湿式消火法で得たコーク スの方か $\mathrm{H}_{2} \mathrm{O}$ 含有量が多いというデータを報告してい る.

したがつてコークス中の細孔内吸着水は消火過程の水 分に関係があると思われるが，その粒度依存性について の原因はまだ確認するにはいたらなかつた。しかしこの 点に関しては未乾留成分が，コークスと水分との物理吸 着に何らかの役割をむつたのではないかと考光たい。

\section{3 コークス揮発分中の水素量と 炭素量の温度および 粒度依存性について}

3.2 の項では細孔内吸着水について調査したが，ここ では，残された水素源成分である遊離水素と炭化水素に ついての水素気化量の温度および粒度依存性, 揮発分中 の炭素量の温度および粒度依存性, 揮発分中の $\mathrm{C} / \mathrm{H}$ の 温度および粒度との関係, さらに水素気化量を表わす実 験式などについて調查した。

Fig. 4 によると, 付着水と細孔内吸着水が多量含まれ ている粒度の小さいコークス $(4 \cdot 3 \sim 10 \mathrm{~mm})$ でも $500^{\circ} \mathrm{C}$ 近傍で水分がなくなつて平衡に達していることが分かつ たので，本試験に供する試料は予め別炉で $500^{\circ} \mathrm{C} て ゙ 30$ $\min$ 間加熱して, コークス中の付着水と細孔内吸着水 を除去したものを用いた，その他の実験条件は Table $1 の(\mathrm{C})$ にもとゔいて行なつた.

得られた結果は次のとおりである.

3.3.1 コークス揮発分中の 水素量の温度および粒度 依存性について

Fig. 6 亿各温度, 各粒度における水素気化量（試料量 に対する割合）と水素気化率（各条件下における水素気 化量の 総水素量に対する割合）の時間との関係を示し た.これらから水素気化量についてつぎのことがわか る.

（1）温度依存性を示すこと.

（2）粒度依存性を示すこと.

（3）温度依存性の方が強いこと.

（4）いずれの温度の場合も試料捜入後，10２0 min の間で水素が急激に発生し，60〜70 min 後に平衡達 してしまうこと.

（5） $1100^{\circ} \mathrm{C}$ をでの温度領域では， 3 種の実験粒度 範囲での水素気化率は総水素量の 20～50\% であること がわかる.

このように水素気化量が温度と粒度に依存することに ついては次の検討を行なつた.

まず温度依存性を確認するために次の実験を行なつ た.すなわち，ある粒度の試料を $700^{\circ} \mathrm{C} て ゙$ 加熱して水 素を気化させ. 平衡に達したら,ただちに $900^{\circ} \mathrm{C}$ に昇 温し，その温度で平衡に達したら，また，ただちに 1100 ${ }^{\circ} \mathrm{C}$ に昇温する. このようにして各温度段階における平 衡値が，それぞれの温度における単純平衡值 $\left(500^{\circ} \mathrm{C}\right.$ か ら $700^{\circ} \mathrm{C}, 500^{\circ} \mathrm{C}$ から $900^{\circ} \mathrm{C}, 500^{\circ} \mathrm{C}$ から $1100^{\circ} \mathrm{C}$ と それぞれ単独に昇温した場合の平衡值）の箅囲内におさ をるかどうかを確認する実験を行なつた。

Fig. 7 にこの実験結果を示した. このことからも水素 の気化量は温度に大きく依存することが明白である. 


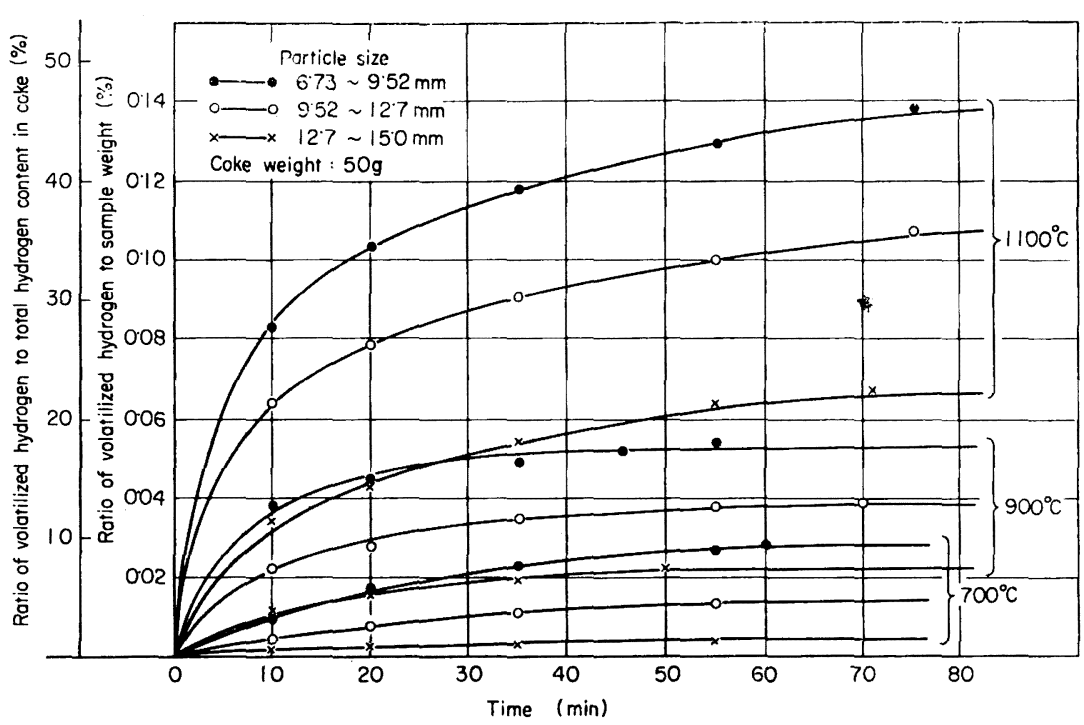

Fig. 6 . Dependency of volatilized hydrogen on temperature and particle size.

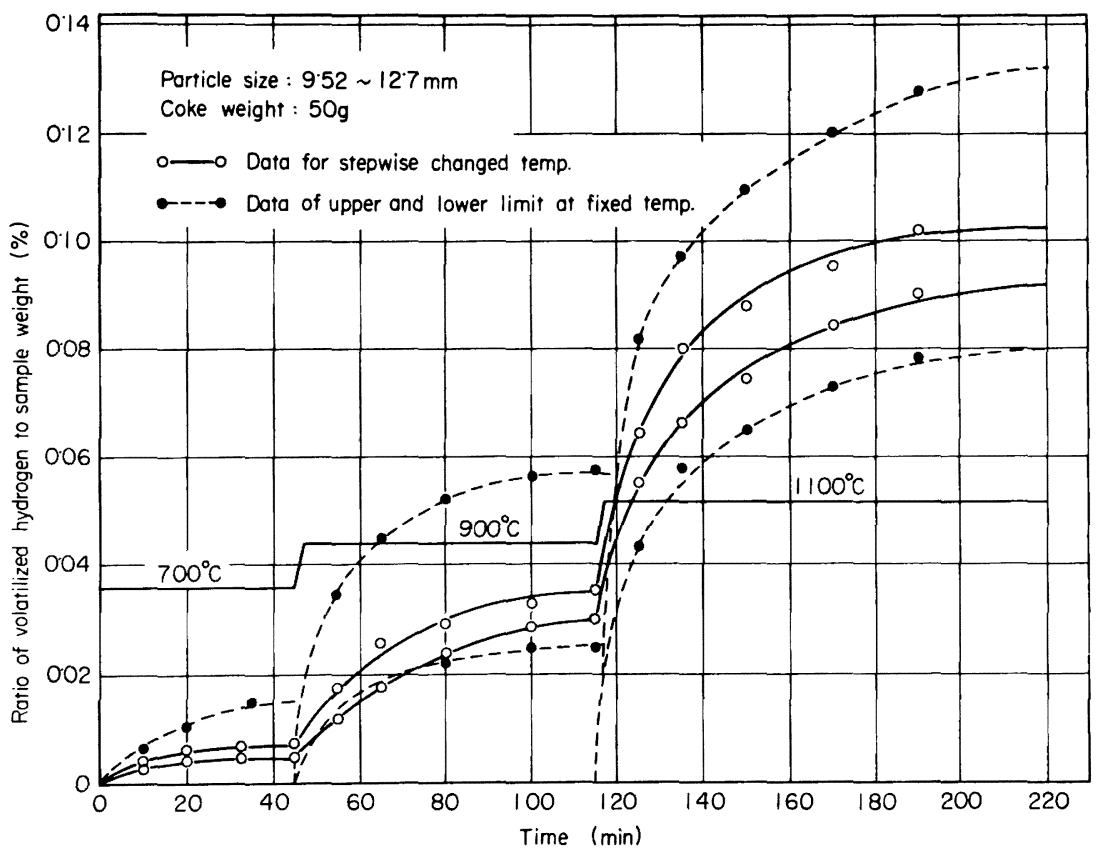

Fig. 7. Volatilized hydrogen for stepwise changed temperature.

次に粒度依存性についてであるが，この原因としては 次の場合が考えられる.

（i）小粒コークス中に末乾留コークス部分が多量含 まれている。

（ii）小粒コークスは表面䅡が大きいため，大気中に さらされている間に付着水, 遊離水素, 炭化水素系ガス

\section{を多量吸着する。}

そこで，この（i ），(ii)のいずれに起因するかを検討 するために次の実験を試みた。

試料として :

(a) 初期粒度 $12 \cdot 7 \sim 15 \cdot 0 \mathrm{~mm}$ のコークス.

(b)（a）のコークスを粉砕して 3.36〜5.66 mm に 


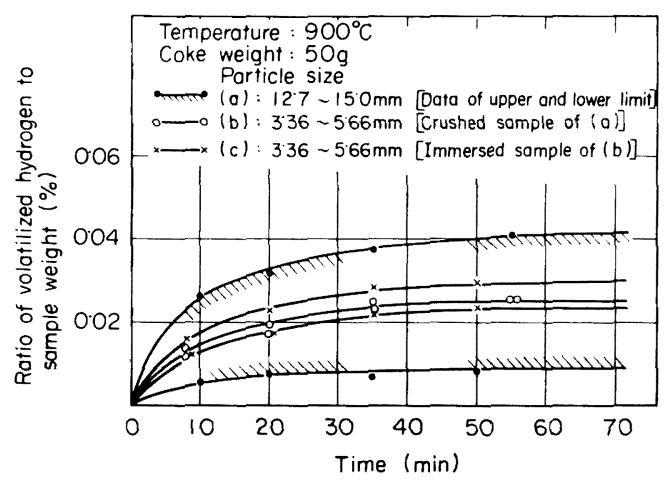

Fig. 8. Volatilized hydrogen when changed pretreatment of coke.

\section{したもの。}

（c）（b）のコークスを一昼夜水中に浸したもの.

上記の予備処理の異なるコ一クスについて同一条件に て実験を試み，3者を比較した。

この結果を Fig. 8 に示した. これから(b)，（c）の いずれの試料も(a) 試料の水素気化量の範囲内におさま つていることから，同一揮発分組成のコークスは粒度と 無関係に 水素気化量は一定值となり, 付着水, 遊離水 素, 炭化水素系ガスの吸着による影響はないものと考え られる。

したがつて小粒コークス帆に水素量が多い理由として は上記 (i ) と考えるのが妥当のようである.
なお，小粒コークス中に末乾留コークス部分が多量集 中する過程は次のようであると考えられる.

コークスの乾留過程で，コークス炉に温度分布が生 じ，高温の壁際は乾留度が高くコークスは緻密でかつ堅 い頭部を形成する．低温側は乾留度が低く脆い足部を形 成する. したがつてコークスを破砕する過程で, 乾留度 の低い足部は脆いために，容易にこわれ小粒コークスに なり易い. その結果として粒度の小さいものほど揮発分 中に水素が多量含まれたものと思われる.

$3 \cdot 3 \cdot 2$ コークス揮発分中の炭素量の温度および粒度 依存性について

Fig. 9 に各温度，各粒度における炭素気化量（試料量 に対する割合）の時間との関係を示した：これから炭素 の気化量は温度に大きく依存するが, 粒度依存性は水素 の場合ほど明瞭でなく, 各温度によつてまちまちで水素 の場合と同様な傾向はみられない. $700^{\circ} \mathrm{C}, 1100^{\circ} \mathrm{C}$ の 場合の気化量の上・下限の範囲が小さいこととデータの バラツキを考虑した場合，炭素の気化量には粒度依存性 がほとんどないと考えられる。

$3 \cdot 3 \cdot 3$ コークス揮発分中の $\mathrm{C} / \mathrm{H}$ の温度および粒度 との関係

Fig. 6 とFig. 9 の各温度, 各粒度における水素と炭素 の平衡気化量から $\mathrm{C} / \mathrm{H}$ を求め, これの温度および粒度 との関係を Fig. 10 に示した。これから温度が低く，粒 度が大きいものほど $\mathrm{C} / \mathrm{H}$ の重量比が高くなつており,

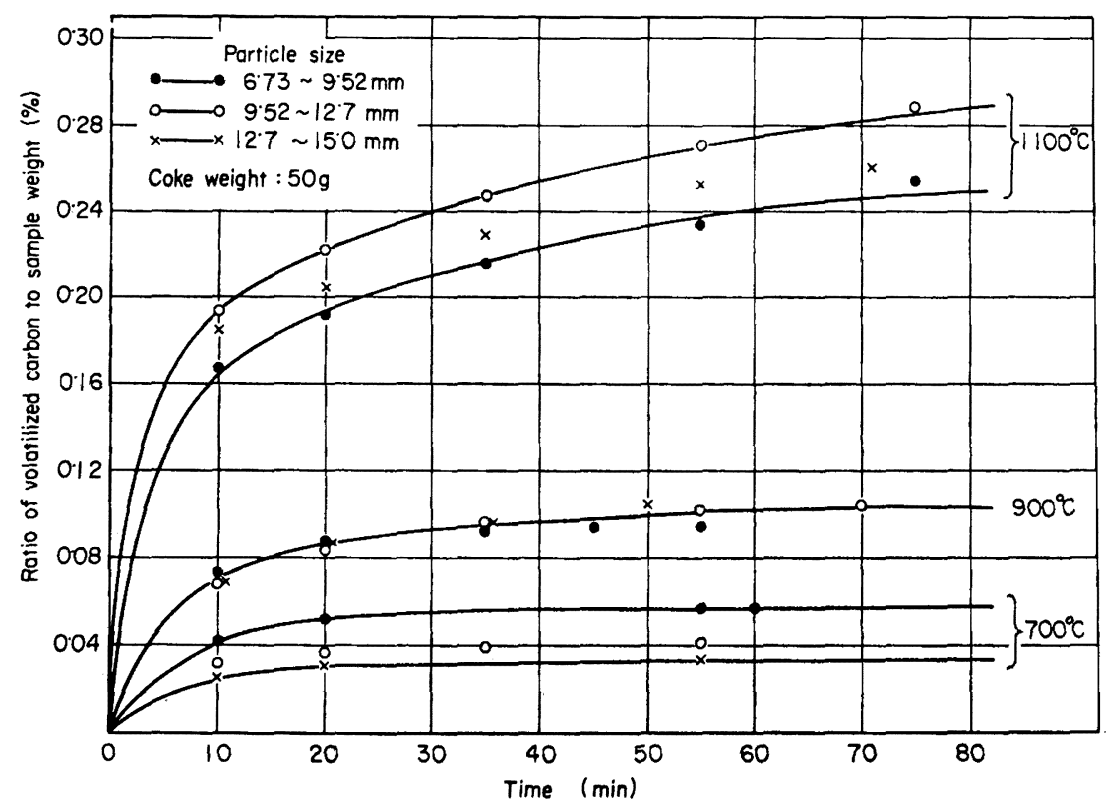

Fig. 9. Dependency of volatilized carbon on temperature and particle size. 


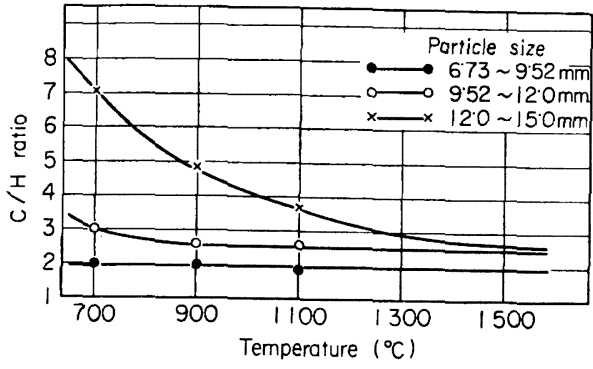

Fig. 10. Relation between temperature and $\mathrm{C} / \mathrm{H}$ ratio on several particle sizes.

温度が高くなるにしたがつて C / H の比が減少すること がわかる。

飯島ら2)はコークス揮発分の主成分は遊離水素と CO ガスで，温度が高くなるにつれて $\mathrm{H}_{2}$ 増加する傾向を 示すが，CO はやや緩慢な形で増加すると述べている. 彼らの結果を当実験における C/H の温度依存性でみる と, Fig. 10 の傾向は 飯島らの得た 結果とも一致するよ うに思われる.

Fig. 10 にて, 温度がさらに高くなつて 揮発分が完全 になくなる時点の $\mathrm{C} / \mathrm{H}$ の重量比はこのグラフの延長線 上で表わされ，その時の $\mathrm{C} / \mathrm{H}$ とコークス粒度との関係 をFig.11に示した. したがつて，コークス揮発分中の $\mathrm{C} / \mathrm{H}$ は $2 \cdot 0 \sim 2.6$ の範囲内にあることがわかる。また Fig. 10 から揮発分が完全になくなる温度は $1500^{\circ} \mathrm{C}$ 近 傍であると推定される.

3.3.4 コークス揮発分中の水素気化量を表わす実験 式

コークス中の水素気化量のデータを高炉のデータ解析 に適用する場合，水素気化量を定量的に解析する必要が ある。

本来, 水素の気化量を速度式の形でモデル的に解析す ることが理想的であるが，水素の気化機構の実体が不明 瞭なため解析は非常に困難である，したがつてここでは 水素気化量を当実験で得たデータから実験式として定量 化を試みた。

Fig. 6 の水素気化率曲線の平衡点に達した值を平衡気 化率とし，この値を各温度，各粒度に関して表わしたの が Fig. 12 である.これより水素気化率 $(W)$ は温度 $(T)$ について対数関係にある. したがつて各粒度についてW は $T$ について(1)式で表わされる.

$\log W=\log A+B \cdot T$

Fig. 12 から各粒度の 水素気化率を求めると次式を得 る.

粒度 $6 \cdot 73 \sim 9 \cdot 52 \mathrm{~mm}$ :

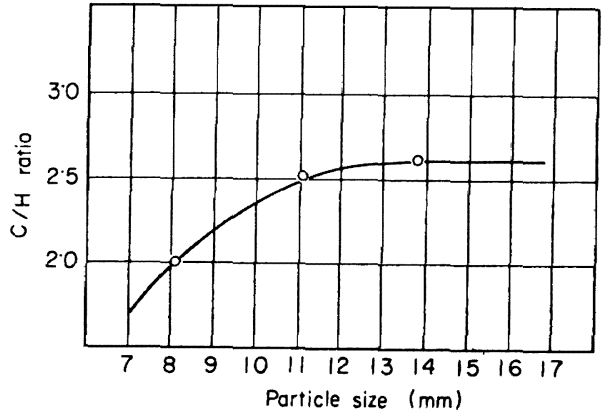

Fig. 11. Relation between particle size and $\mathrm{C} / \mathrm{H}$ ratio.

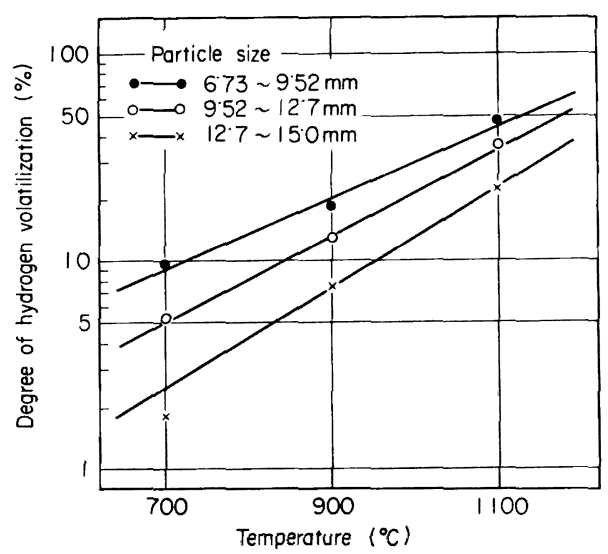

Fig. 12. Relation between temperature and degree of hydrogen volatilization at equilibrium state of Fig. 5.

$\log W=\log 56 \cdot 87 \times 10^{-2}+17 \cdot 13 \times 10^{-4} \cdot T$

粒度 $9.52 \sim 12.70 \mathrm{~mm}$ :

$\log W=\log 18 \cdot 27 \times 10^{-2}+20.63 \times 10^{-4} \cdot T \cdots(3)$ 粒度 $12 \cdot 70 \sim 15 \cdot 0 \mathrm{~mm}$ :

$\log W=\log 5 \cdot 27 \times 10^{-2}+23 \cdot 95 \times 10^{-4} \cdot T$

したがつて(1)式中の定数 $A, B$ を(2)，(3)，(4) 式から選び出し，平均粒度との関係を調べると，定数 $A$ は粒度と対数関係にあり, 定数 $B$ は粒度と一次の関係に あることがわかる．この $A, B$ と粒度 $(D)$ との関係式を 求めると次式を得る.

$$
\begin{aligned}
& A=17 \cdot 7 \times 10^{-18.1 \times 10^{-2} . D \ldots \ldots \ldots \ldots \ldots} \\
& B=1 \cdot 214 \times 10^{-6} \cdot D+7 \cdot 193 \times 10^{-6}
\end{aligned}
$$

したがつて (5)，（6)式を(1)式に代入すると水素気 化率の温度と粒度への依存性を表わす次の実験式を得 る. 
$\log W=\log 17 \cdot 7 \times 10^{-18.1 \times 10^{-2}} . D$

$+\left(1 \cdot 214 \times 10^{-6} \cdot D+7 \cdot 193 \times 10^{-6}\right) T$

ここで, $W:$ 水素の気化率 $(\%)$

$D:$ コークスの平均粒度 $(\mathrm{mm})$

$T:$ 気化温度 $\left({ }^{\circ} \mathrm{C}\right)$

\section{4. 結}

言

コークス揮発分中に含まれる水素量と炭素量の温度お よび粒度依存性に関する基礎的調査を行ない次のような 結果を得た。

（1）揮発分中の水素は粒度が小さいものほど多量に 含まれている。

（2）揮発分中に含まれる水素は, 生産高炉用コーク 粒度では，ほとんご遊離水素と炭化水素系成分からく る 水素であり, $10 \mathrm{~mm}$ 以下の 粒度範囲では, コークス 中水素絶対量の約 $10 \%$ 近くが細孔内吸着水由来の水素 である・

（3）揮発分中の水素の気化量は温度と粒度の影響を
受け，しかも温度の影響がより顕著である.

(4) $10 \mathrm{~mm}$ 以下の粒度範围では, $100 \sim 1100^{\circ} \mathrm{C}$ の 温度領域で全水素の約 $60 \%$ 弱まで気化するが，残り 40 $\%$ 強の水素は $1100^{\circ} \mathrm{C}$ 以上の温度域で放出されるもの と推定される.

（5）揮発分中の元素主成分は水素と炭素であり，こ の結合形態については不明であるが，比較的広い粒度範 囲にわたつて揮発分中の炭素は重量比で水素量の $2 \cdot 0$ 〜 $2 \cdot 6$ 倍多く含んでいる.

（6）揮発分中の水素気化率の温度と粒度への依存性 を表わす実験式が得られた。

\section{交献}

1) 城, ほか: 鉄と鋼, 47 (1961) 3, p. 263

2 ）飯島，ほか：コークス技術年報，コークスシリー ズ, 11 (1961), p. 50

3 ) 日本分析化学会編: 分析化学便覧, (1971), p. 256 [丸善]

4 ) 学振製鋼 19 委員会: 鉄鋼化学分析全書 10 , (1963)，[日刊工業新聞社] 